\title{
Scientists and Their Schools: Grigoriy Vitalyevich Khlopin (1863-1929), Professor at Yuriev (Tartu) and Odessa Universities
}

\author{
Kostyantyn Kostyantynovich Vasylyev \\ Odessa National Medical University \\ Valikhovskiy Lane 2, \\ Odessa 40007, Ukraine \\ E-mail: vasylyev-sumy@mail.ru

\section{Yuriy Kostyantynovich Vasylyev} \\ Sumy State University \\ Rimskiy-Korsakov 2, \\ Sumy 40007, Ukraine \\ E-mail:vasylyev-sumy@mail.ru
}

An extensive body of literature is devoted to the life and work of one of the leading hygienists Grigoriy Vitalyevich Khlopin, who was head of the Department of Hygiene at the University of Yuriev (present-day Tartu) in 1896-1903 (Loit, Loit \& Kalnin, 1968; Belitskaya, 1982). Major encyclopedias published in Russia include biographical entries about him (Shishkin, 1978; Koshelev, 1985). In addition, Khlopin's background is given in both general biographical dictionaries and other biographical books of the universities where he worked (Levitskii, 1903; Zolotarev, Ilyin \& Luki, 1992; Volkov \& Kulikov, 2003). Notable among these are the monographs by A. A. Rachkov (1965) and A. P. Shcherbo (2006). However, the former was published nearly half a century ago and was, in some respects, outdated, and the latter concentrated on the analysis of the final, the St. Petersburg period in Khlopin's academic activities.

This article aims to provide a more detailed study on the establishing and the initial phase of Khlopin's scientific and hygienic school during the Yuriev period of his activity. Khlopin's Yuriev period was followed by his stay in Odessa, where he was joined also by some of his Yuriev students (Alexander Rammul, Konstantin Dobrovolsky, and Ivan Brickman). The study includes several archival materials from the Moscow and Novorossiysk (Odessa) universities, many of which were first introduced by the authors of this article for scientific discovery. 
On November $15(27)^{1}, 1896$ Khlopin, M.D., dissector of the Department of Hygiene at Moscow State University, was appointed supernumerary extraordinary professor of the Department of Hygiene at the University of Yuriev (where in 1899 he became a full professor) by the Imperial Majesty's order of the Civil Department. By that time he had worked in Professor Fyodor Erisman's (1842-1915) hygienic laboratory of the Moscow University for more than five years. Erisman, in turn, was a disciple of the founder of experimental hygiene, the German Max von Pettenkofer (1818-1901). Khlopin started his work at Professor Erisman's hygienic laboratory while he was still a student of the medical faculty. Since 1894 he continued his work at the university to prepare for a professorship (TsIAM, 1712-1928a). Under Erisman's lead he prepared for Dr. Med. degree, which he was granted in 1896 (TsIAM, 1712-1928b; c).

In Tartu, sanitary-chemical and microbiological as well as sanitary-toxicological experimental studies were conducted in Professor Khlopin's laboratory and under his supervision. The following works on environmental sanitation and food hygiene were carried out:

"Chemical-sanitary research into selling milk in the town of Yuriev" (S. Ginsburg, 1897);

"Chemical and bacteriological study on artificial mineral water in the town of Yuriev" (A. Zimmerman, 1900);

"Analysis of some methods of determining fiber" (K. Beck, 1900);

"Soap, its chemical composition and disinfectant properties" (F. Rogengagen, 1900);

"Chemical health bacteriological examination of selling butter in the town of Yuriev" (B. Lorenz, 1901);

"Further studies on the dangers of oil products for fish and warm-blooded animals" (J. Kupzis, 1901);

"Materials for the study of soil air under residential premises" (I. Treiman, 1901);

"The chemical composition of some mineral springs and muds in Eastern Siberia” (F. Ludwig, 1902);

"Further research into the disinfection properties of naphthenic acids and their salts" (G. Spalving, 1902);

"Study on sausages and minced meat" (A. Zennig, 1903);

"Study on Russian tobacco and cigarette smoke" (I. Pontag, 1902).

\footnotetext{
Hereinafter the date is given in Old Style, followed by the New Style date in parenthesis.
} 
Most noteworthy among these is the study by Janis Kupzis (1871-1936), who graduated from the University of Yuriev as pharmacist in 1895 . He determined the oxygen concentration in water necessary for fish. He was the first to establish which petroleum hydrocarbons and in which concentrations were detrimental to fish and found that naphthenic acids were more toxic than hydrocarbons and nitrogen base oil. Since 1921, Kupzis worked in Riga. He became one of the first researchers of the chemical composition of mineral waters and mud in Latvia, and from 1927 till the date of his death he worked as a professor of pharmacy at University of Latvia (Ruplis \& Grosvalds, 2000).

In 1899, Alexander Rammul (1875, Tartu - 1949, Berlin) graduated from the Medical School of the University of Yuriev and the following year became supernumerary assistant to Professor Khlopin, under whose lead he held his first hygiene study. Konstantin Erastovich Dobrovolsky (1867-1946), a graduate of the Medical Faculty of Moscow University from 1895, started his work at Khlopin's health laboratory in 1901, and since 1902 Ivan Brickman (1874-?) worked there. In 1899, Brickman received a pharmacist diploma from the University of Yuriev and since 1902 he conducted a study on lead-glazed pottery utensils as part of sanitary ware at Khlopin's laboratory and at his suggestion. The fate of Ivan Brickman after the 1917 revolution remains, unfortunately, unknown.

The Imperial Majesty's order to transfer Khlopin to full professorship to the Novorossiysk University (NU) in Odessa was issued on June 20 (July 3), 1903 (DAOO, n.d.a). At Khlopin's request, Alexander Rammul became laboratory assistant at the Odessa department. Upon hearing about the intended move of his supervisor to Odessa, Rammul wrote a petition to the NU Medical School laboratory already on April 14 (27), 1903 concerning his appointment as a laboratory assistant of the health laboratory and Khlopin, in turn, wrote a postscript to the letter to support his student. On September 10 (23), 1903 Rammul was elected to the position by the faculty and on November 10 (23) the same year, the trustee of the Odessa School District agreed to his move to Odessa (DAOO, n.d.,b, c). Professor Khlopin responded to the requests and suggestions made by the board of NU Medical School on health assessment of central heating and ventilation in the faculty buildings, such as medical laboratories and the faculty's surgical clinic.

The corresponding study was conducted by his laboratory assistant Rammul, who later presented it as the thesis for his Doctor of Medicine degree. The successful defense was held at the NU Medical School in 1909 (DAOO, n.d.,d,e). Rammul left Odessa when Professor Khlopin left NU, after being dismissed from his post in accordance with a petition dated to February 22 (March 6), 1905. Since 1905, 
Rammul worked in Moscow as head of the laboratory of the Moscow water filtration plant in Rublevo. In 1907, he was sent abroad by the Moscow city government to review plumbing industry. He visited Berlin, Hamburg, Bremen, Zurich, as well as the city of Paderborn (Westphalia) and Schierstein (a suburb of Wiesbaden). Since 1912, Rammul worked as an assistant professor at the Department of Hygiene of Moscow University (TsIAM, 1712-1928d). From 1915 to 1920 he headed the Department of Hygiene at Kazan University and later at the University of Tartu in 1920-1940. There he continued to develop Khlopin's research areas as well as to maintain contact and exchange books with him.

Konstantin Dobrovolsky followed Professor Khlopin from Yuriev to Odessa. Dobrovolsky began to write his thesis "Study on the sensitivity for determining the coal color most commonly used in sanitary practice methods" at Khlopin's laboratory in Yuriev and finished the study in Odessa, working at Khlopin's laboratory without pay. On May 23 (June 5), 1904, in a public meeting of the NU Medical School he successfully defended his dissertation and on May 27 (June 9), 1904 was granted the Doctor of Medicine degree by the NU board (DAOO, n.d.,f, pp. 1-24; g). Dobrovolsky demonstrated the necessity of sanitary and toxicological studies of chemical substances used in food industry and also developed methods for identifying these in sanitary practices.

Professor Khlopin gave the following description of his student [March 2 (15), 1904]:

Dr. Dobrowolski has been working in my laboratory in Yuriev and Odessa for almost three years, even though he came for only one semester in order to study health research methodology. Due to his natural tendency to theoretical science, Dr. Dobrowolski became interested in laboratory business and, at my suggestion, filled the post of the second assistant without any compensation from the university and he continues to engage in research to date. In addition to gaining considerable skills in laboratory engineering and basic information on hygiene, Dr. Dobrowolski carried out a very solid special study during that time which has already been completed [...]. Dr. Dobrowolski not only worked under my supervision, but supplemented his knowledge primarily in bacteriology at Professor M. Rubner's Institute of Hygiene in Berlin, again at his own expense. (DAOO, n.d.,f, p. 12)

After the thesis defense, Dobrovolsky followed Professor Khlopin to St. Petersburg, where he was appointed a lecturer at St. Petersburg Women's Medical Institute. 
In 1910-1914, he held the Chair of Hygiene at Kazan University. Since 1914, Dobrovolsky was Chair of the Department of Hygiene of the Medical Faculty at the Imperial St. Vladimir University in Kiev, and during the years of the Civil War in Russia at the Tauride University in Simferopol (in 1919-1923). In 1923-1932 he was Chair of the Institute for Advanced Medical Studies in Leningrad, after which he returned to Kiev.

In 1904, another Khlopin's student-Ivan Brickman-defended his thesis at the NU Medical School. He began his research into lead-glazed pottery utensils in sanitary ware in Khlopin's Yuriev laboratory. In relation to Khlopin's move to Odessa, Brickman finished his work by defending it as a thesis for the Master of Pharmacy degree.

On November 1 (14), 1904 Professor Khlopin was appointed full professor at St. Petersburg Women's Medical Institute and since November 16 (29) the same year, he acted as head of the medical-sanitary institutions of the Ministry of Education. The Odessa period of his life and work ended and the St. Petersburg period, which remained his last, began.

In summary, it must be said that in his research, Professor Khlopin, a hygienist of wide specialization, continued to develop the experimental course in the field of hygiene of Professor F. Erisman, his teacher (and of M. von Pettenkofer, the teacher of his teacher). However, he also introduced new laboratory methods to the study of hygiene. This is particularly evident in his scientific school which was started in Yuriev. In addition, the tendency to solve practical problems that medicine was facing, as can be seen from the selection of academic subjects that Khlopin gave to his students, is characteristic of his scientific and hygienic school. It should also be noted that the scientific work that Khlopin's students started in Yuriev was continued and developed further in Odessa. Both the Odessa hygienic laboratory and the one in Yuriev were closely linked to each other during that period. 


\section{References}

Belitskaya, E. A. (1982), Nauchnye gigienicheskie shkoly Leningrada [Scientific hygienic schools in Leningrad], Leningrad: Meditsina.

DAOO (n.d., a), DAOO f 45, op 4, d 1723, ll 1-31, The State Archives of the Odessa Region, Odessa.

— (n.d., b), DAOO f 45, op 4, d 1575, ll 1-35, The State Archives of the Odessa Region, Odessa.

— (n.d., c), DAOO f 45, op 4, d 1576, ll 1-6. The State Archives of the Odessa Region, Odessa.

— (n.d., d), DAOO f 45, op 22, d 31, 11 253-258. The State Archives of the Odessa Region, Odessa.

— (n.d., e), DAOO, f 45, op 18, d 289, 11 25-35, 52-53. The State Archives of the Odessa Region, Odessa.

— (n.d., f) DAOO f 45, op 4, d 1256, ll 1-24, The State Archives of the Odessa Region, Odessa.

- n.d., g) DAOO, f 45, op 18, d 132, 11 35-37, The State Archives of the Odessa Region, Odessa.

Koshelev, N. F. (1985), 'Khlopin Grigori V.', in Bolshaia meditsinskaia entsiklopedia, 3rd ed., Moscow: Sovetskaia entsiklopedia, vol. 22, pp. 555-556.

Levitskii, G. V., ed. (1903), Biograficheskii slovar professorov I prepodavatelei Imperatorskogo Yurievskogo, byvshego Derptskogo universiteta za 100 let ego sushchestvovania [Biographical dictionary of professors and lecturers of the Imperial Yuriev, former Dorpat University in the 100 years of its existence], Yuriev, vol. 2, pp. 229-232.

Loit, A. O.; Loit, R. L. \& Kalnin, V. V. (1968), 'K voprosu o roli shkoly G. V. Khlopina $\mathrm{v}$ razvitii sovetskoi gigieny' [The role of G. V. Khlopin's schools in the development of Soviet hygiene], in Materialy $k$ konferentsii po istorii estestvoznania v Pribaltike, Vilnius, pp. 117-119.

Rachkov, A. A. (1965), Grigorii Vitalevich Khlopin. (Zhizn i deiatelnost) [Grigori V. Khlopin. (His life and work)], Leningrad: Meditsina.

Ruplis, A. \& Grosvalds, I. (2000), 'Janis Kupcis - Latvijas mineraludenu un dziedniecibas dunu petnieks', Acta medico-historico Rigensia, Riga, vol. 5, pp. 237-246.

Shcherbo, A. P. (2006), Grigorii Vitalevich Khlopin. Listaia stranitsy istorii [Grigori V. Khlopin. Leafing through the pages of history], Petersburg.

Shishkin, A. P. (1978), 'Khlopin Grigori V.', in Bolshaia Sovetskaia Entsiklopediia, Moscow: Sovetskaia entsiklopedia, vol. 28, p. 302.

TsIAM (1712-1928a), Moskovskii Imperatorskii Universitet, TsIAM f 418, op 62, d 385, 1l 1-47, Central Historical Archive of Moscow, Moscow.

(1712-1928b), Moskovskii Imperatorskii Universitet, TsIAM f 418, op 65, d 207, 
1l 1-14, Central Historical Archive of Moscow, Moscow.

— (1712-1928c), Moskovskii Imperatorskii Universitet, TsIAM f 418, op 403, d 13, ll 1-14, Central Historical Archive of Moscow, Moscow.

—_ (1712-1928d), Moskovskii Imperatorskii Universitet, TsIAM f 418, op 418, d 123, 11 1-8, Central Historical Archive of Moscow, Moscow.

Volkov, V. A. \& Kulikov M. V. (2003), Rossiiskaia professura XVIII - nachalo XX v. Biologicheskie i mediko-biologicheskie nauki. Biograficheskii slovar [Russian professors of the $18^{\text {th }}-$ early $20^{\text {th }}$ century. Biological and biomedical sciences. Biographical Dictionary], Petersburg: Izd-vo Russkogo Khristianskogo gumanitarnogo in-ta, pp. 464-465.

Zolotarev, A. E.; Ilyin, I. I. \& Luki L. G. (1992), Biograficheski slovar professorov Odesskogo meditsinskogo instituta imeni N. I. Pirogova (1900-1990) [Biographical Dictionary of professors of Odessa Medical Institute named after N. I. Pirogov (1900-1990)], Odessa: Odes. gos. med. in-t, p. 267. 